\title{
SEASONAL DYNAMICS OF WOOD FORMATION IN PINUS HALEPENSIS FROM DRY AND SEMI-ARID ECOSYSTEMS IN SPAIN
}

\author{
Martín de Luis ${ }^{1}$, Jožica Gričar ${ }^{2,3}$, Katarina Čufar ${ }^{3}$ and José Raventós ${ }^{4}$
}

\begin{abstract}
SUMMARY
The seasonal dynamics of cambial activity, wood formation, occurrence of false rings (FR), and tangential bands of resin canals (RC) were investigated in Pinus halepensis from three Mediterranean dry and semi-arid ecosystems in Spain. We collected intact tissues of phloem, cambium, and outer xylem at monthly intervals throughout 2004 from each time six trees at the three sites. Cell divisions in the cambium in all trees started before our first sampling in mid-March and ceased between November and December. Cambial activity was characterized by two maxima; one in spring and another in autumn. Trees still grew in summer but at a very low rate. The first solitary RC were formed in May or June and tangential bands of RC in June or July. In general, tangential bands of RC were observed in wider growth rings. The formation of tangential bands of RC seems to be induced by drought in the second half of the growing season. FR were formed as a result of cambial reactivation in autumn and were observed in growth rings that contained more than 50 cells in a radial row. It appears that summer drought and early autumn precipitation play an important role in false-ring formation.
\end{abstract}

Key words: Aleppo pine, western Mediterranean, cambial activity, wood formation, tracheids, resin canals, false rings.

\section{INTRODUCTION}

In Mediterranean climates, characterized by mild and rainy winters and hot dry summers, the growth and development of trees is not always associated with regular dormancy in the cold season, as it is in temperate or boreal climatic zones (Cherubini et al. 2003).

Thus, the cambial activity of Mediterranean trees can vary from year to year presenting continuous radial growth or one or two growth interruptions in line with the variability of climatic conditions. Then, the cambium can activate in spring, remain active in summer and enter dormancy in winter, as in the temperate climate zone. Under favourable climatic conditions (relatively warm winters and relatively cold

1) University of Zaragoza, Dept. Geografía y O.T. C/ Pedro Cerbuna 12, 50009Zaragoza, Spain.

2) Slovenian Forestry Institute, Večna pot 2, SI-1000 Ljubljana, Slovenia.

3) University of Ljubljana, Biotechnical Faculty, Department of Wood Science and Technology, Rozna dolina, Cesta VIII/34, SI-1000 Ljubljana, Slovenia.

4) University of Alicante, Departamento de Ecología, Ap. 99, 03080 Alicante, Spain.

*) Corresponding author: Martín de Luis [mdla@unizar.es].

Associate Editor: Ute Sass 
wet summers) the radial growth of trees can be maintained throughout the whole year while under adverse conditions (mainly related to drought) reactivation of cambium and production of wood may not take place at all (Raventós et al. 2001, 2004). In other circumstances, the trees can be subjected to 'double stress' characterized by two interruptions in cambial activity; one during the winter caused by low temperatures and one during the summer triggered by high temperatures and lack of precipitation (Susmel et al. 1976; Mitrakos 1980; Liphschitz \& Lev-Yadun 1986; Terradas \& Savé 1992 cited by Cherubini et al. 2003; Lev-Yadun 2000). For such conditions, literature often reports on a 'summer halt' in radial growth but it is still unclear whether the cambium really becomes dormant (e.g. Cherubini et al. 2003).

Aleppo pine (Pinus halepensis Mill.) is a widespread and relatively well investigated tree species growing in Mediterranean conditions (Liphschitz \& Lev-Yadun 1986; Barberó et al. 1998; Lev-Yadun 2000). Studies on the seasonal dynamics of cambial growth in Aleppo pine have been carried out in different Mediterranean countries like Israel (Oppenheimer 1945; Liphschitz \& Lev-Yadun 1986), Italy (Messeri 1948; Attolini et al. 1990), France (Serre 1976; Nicault et al. 2001), and Spain (Gutierrez, pers. comm.), mostly by using dendrometers. Dendrometers provide continuous measurements but they do not reflect the entire dynamics of cell production (e.g. Liphschitz \& Lev-Yadun 1986). Histological methods are more precise - although more time-consuming - but enable studying cambial activity at cellular level and provide an accurate estimation of seasonal dynamics mainly in periods when cambial activity is low. Moreover, it becomes possible to explore variation in cell sizes and shapes with time as well as the formation of specific features such as resin canals. In spite of these advantages, histological methods have been rarely used to study wood formation in Mediterranean tree species.

The wood of Pinus halepensis, as in other conifers, is mainly composed of tracheids. The growth rings are regularly composed of earlywood, in which tracheids have relatively large diameters and thin cell walls and latewood, with small tracheids having thick cell walls. Severe conditions during the growing season, such as shortage of water, may disturb gradual transition from early- to latewood by the production of latewoodlike cells within earlywood or earlywood-like cells within latewood (Fritts 1976; Schweingruber 1978; Wimmer et al. 2000; Rigling et al. 2003). The resulting structures in growth rings are called intra-annual density fluctuations, double rings, multiple rings, or false rings (Fritts 1976; Kramer \& Kozlowski 1979). In this paper we will use the term false rings (FR).

False rings have shown to be useful environmental indicators in Austrian pine (Wimmer et al. 2000). As they are frequently observed also in the wood of Pinus halepensis, it was worth investigating whether their occurrence is related to specific climate conditions which would make them suitable for climatic reconstruction. Other features such as an abrupt transition from earlywood to latewood can also be indicators of changing environmental conditions. The indicative value of resin canals, particularly those arranged in tangential bands, for climate-related stress conditions has been reported by several authors (Reid \& Watson 1966; Wimmer \& Grabner 1997; Rigling et al. 2003). However, studies on the timing of their formation throughout the growing period are scarce (Fahn \& Zamski 1970). 
In this study we investigated the formation of the xylem annual growth ring on a cellular level in Aleppo pine (Pinus halepensis Mill.) from three sites in Spain at monthly intervals throughout 2004. The aim was (i) to determine the seasonal dynamics of cambial activity (= wood formation), and the occurrence of false rings and resin canals and (ii) to relate changes in wood features to contemporary climate conditions.

More knowledge on the seasonal dynamics of wood formation in Mediterranean tree species, which often lack distinct annual tree rings (Gartner 1995), is extremely relevant not only for dendrochronologists but also for plantation managers (Priya \& Bhat 1998).
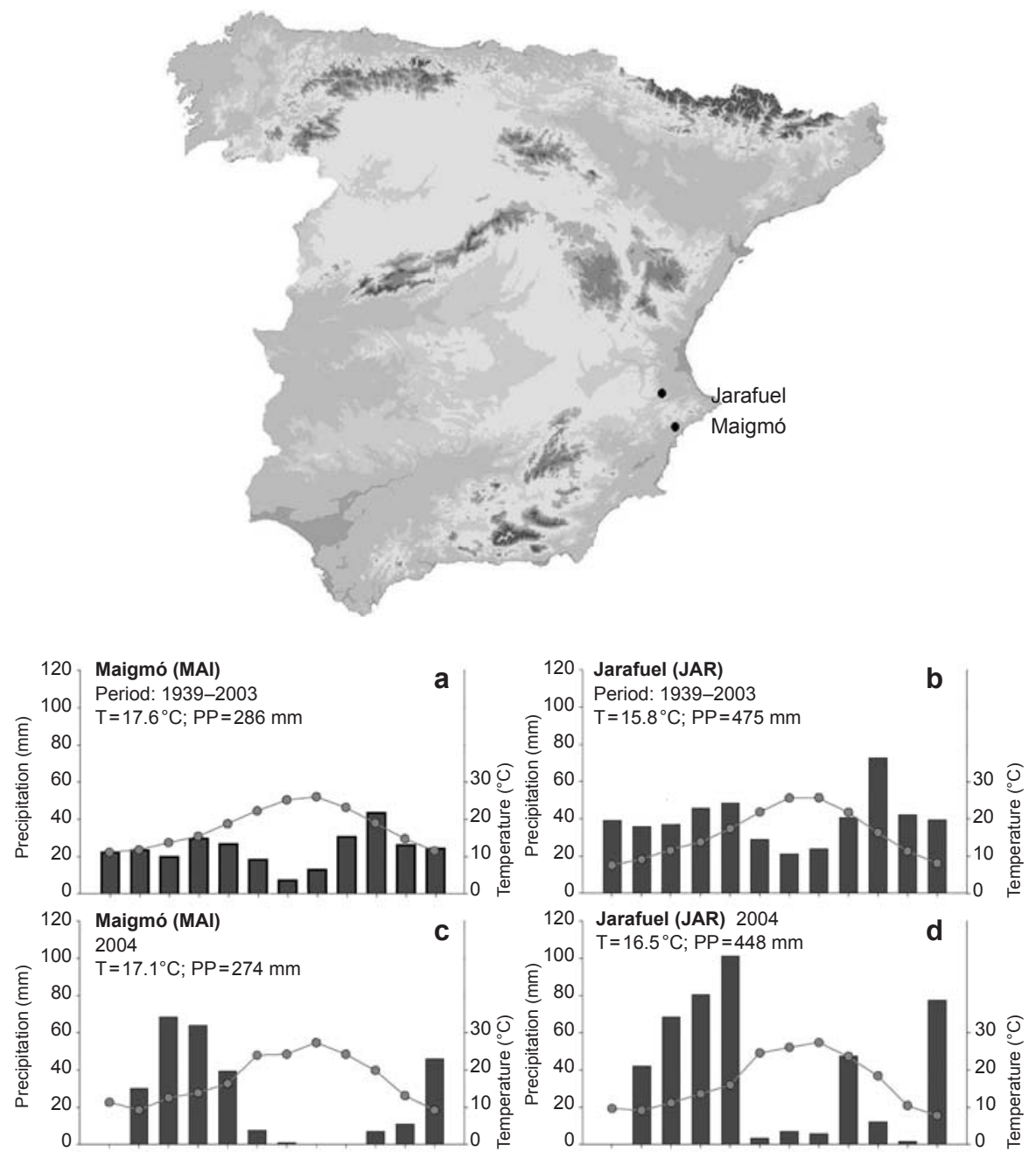

Figure 1. Location of the two sampling sites, Maigmó and Jarafuel, on the eastern Mediterranean coast of Spain; a-b: average monthly rainfall and temperature for Maigmó and Jarafuel for the period 1939-2003; c-d: for 2004, the year of sampling in both sites. 


\section{MATERIALS AND METHODS}

\section{Study sites}

The study was carried out in three plots at two different locations, Maigmó and Jarafuel (Fig. 1). Maigmó (MAI) is located on a north slope at $400 \mathrm{~m}$ a.s.l.; the climate is thermo-mediterranean semiarid (mean annual temperature: $17.6^{\circ} \mathrm{C}$; mean annual sum of precipitation: $286 \mathrm{~mm}$ ). Jarafuel, located at $700 \mathrm{~m}$ a.s.l. comprises two locations, situated at the north (JAN) and south (JAS) slope. The climate is meso-mediterranean and dry (mean annual temperature: $15.8^{\circ} \mathrm{C}$; mean annual sum of precipitation: $475 \mathrm{~mm}$ ).

The average pattern of temperature and distribution of rainfall throughout the year is shown in Figures 1a and b. The two locations are similar in the rainfall distribution, with two maxima in spring and autumn separated by a summer drought due to high temperatures and low precipitation. Maigmó is generally characterized by hotter and dryer conditions than Jarafuel.

Climatic conditions during the study year 2004 at both sites were characterized by above-average precipitation during spring, below-average precipitation in summer and especially dry conditions in autumn at Maigmó. The autumn was also relatively dry in Jarafuel, but rainfall in September was around $40 \mathrm{~mm}$ in contrast with no rain at all in Maigmó (Fig. 1c and d).

In Jarafuel we could select trees on north and south slopes. On the south slope the trees were generally exposed to higher temperatures and more severe drought than those on the north.

\section{Sample trees, sampling procedure and sample preparation}

In total, 162 mature, isolated and healthy Pinus halepensis trees with diameters ranging from 17 to $46 \mathrm{~cm}$ were selected for cambial sampling. Samples were extracted with a chisel and a knife at breast height. In order to avoid effects of wounding due to previous sample extraction, we decided to sample six different trees per plot during each sampling campaign. Sampling was done at monthly intervals from March until December 2004. The cambial samples contained intact tissues of phloem, cambium and outer xylem $(25 \times 10 \times 10 \mathrm{~mm})$. Immediately after removal from a tree the samples were fixed in FEA (formalin-ethanol-acetic acid solution). Sample blocks were then dehydrated in a graded series of ethanol (30\%, 50\%, and 70\%). Transverse sections (25 $\mu \mathrm{m}$ thick) were prepared using a Leica SM 2000R sliding microtome. They were double-stained, first with safranin (0.5\% in $95 \%$ ethanol) and then with astra blue ( $0.5 \%$ in $95 \%$ ethanol), and mounted in Euparal. A Nikon Eclipse 800 light microscope (bright field and polarized light) and Lucia G 4.8 image analysis system were used for observations and semi-automatic counting and measuring of cells and tissues at various stages of their development.

In April 2005, approximately 5-cm-long cores were taken with a standard increment borer from every sampled tree to measure and count the total number of cells in the fully formed growth ring 2004 as well as to verify whether a false ring was formed or not.

\section{Histological analysis}

We followed the seasonal dynamics of xylem formation by distinguishing among cambial cells (CC), differentiating tracheids [postcambial growth (PC), secondary cell 

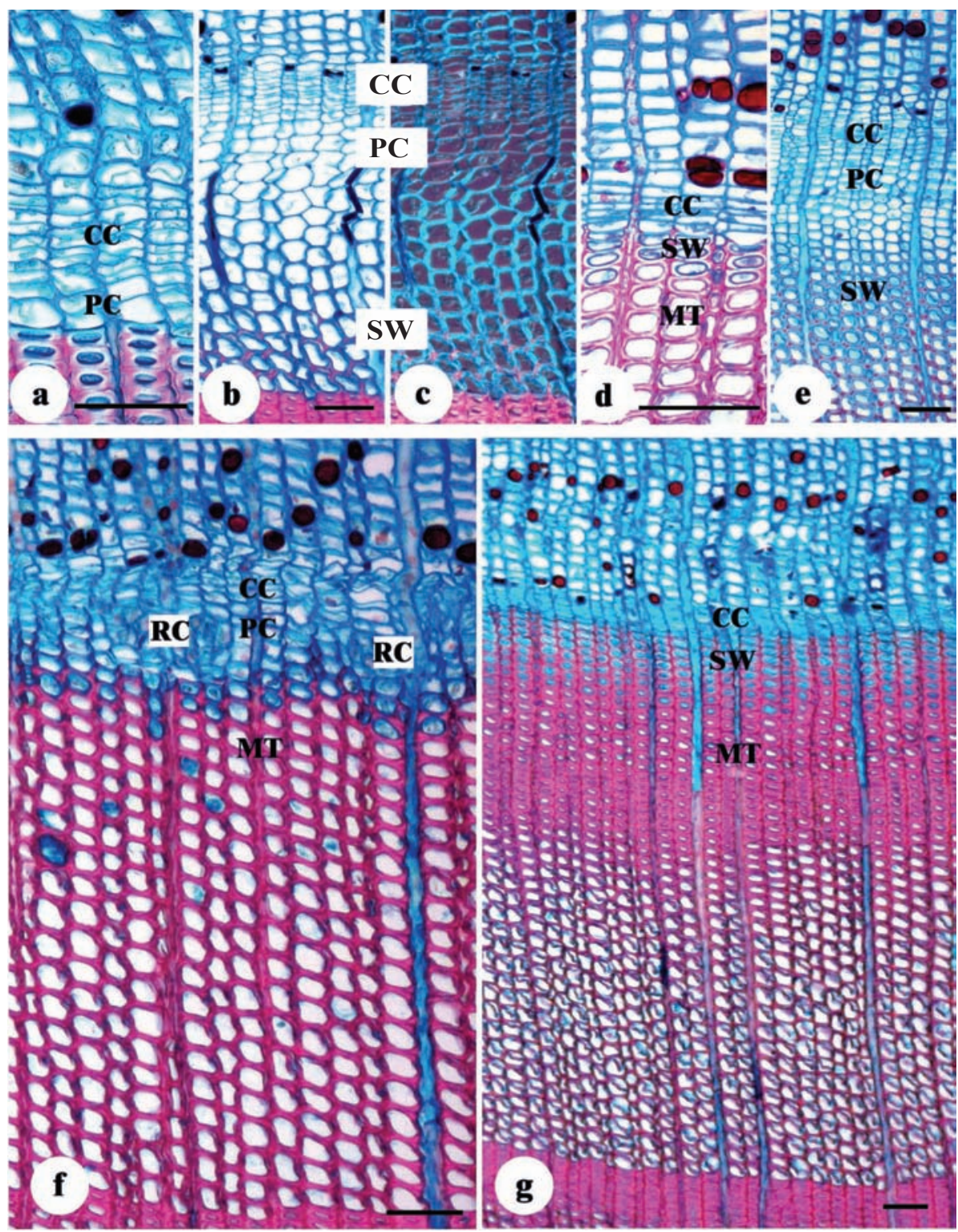

Figure 2. Transverse sections of Pinus halepensis. - a: Activation of the cambium (CC) in March 2004 with enlarging thin-walled PC cells below the cambium. - b \& c: Bright field and polarized light to differentiate PC from cells in the phase of secondary wall (SW) formation in a sample from May. - d: Radially flattened cambial cells (CC) during summer cessation and last formed tracheids in the SW phase. - e: Reactivation of the cambium in September, with new PC cells between CC and SW. - f: Resin canals (RC) in July surrounded by PC and SW cells. - g: False ring 2004 in December with the last formed tracheids still undergoing the final stages of differentiation. - Scale bars $100 \mu \mathrm{m}$. 
wall formation and lignification (SW)] and mature tracheids (MT) (Fig. 2a, b, d). The cambium consisted of radially flattened cells with thin, non-lignified primary cell walls that stained blue with astra-blue. PC cells were defined by larger radial dimensions and thin, non-lignified, blue-stained cell walls. Deposition of secondary wall (SW) layers was observed under polarized light (Fig. 2c) as the cell walls showed birefringence and the thickness of the originally thin cell walls started to increase. The beginning of cellwall lignification could be observed as the red staining by safranin gradually replaced the blue staining, progressing from the outer parts of the cell wall towards the lumen. When the process of differentiation was completed, the cell walls of mature tracheids (MT) were completely red stained and the cell lumina were empty (Fig. 2d).

In all tree rings we selected three radial files to count the number of cells in each developmental phase for the last-formed ring 2004 (PC, SW, MT) and the number of cells in the previous tree ring (PR) (Table 1). We also examined the time of initiation and frequency of axial resin canals (RC). They were characterized by large, thin-walled secretory cells bordering the canal (Schweingruber 1996), which stained blue. We also recorded the time of formation of resin canals and whether they were present solitarily or in tangential bands. In all samples the radial dimensions of tracheids and the thickness of cell walls were determined in order to (i) evaluate the transition from earlywood to latewood by defining the time when first fully developed latewood cells occurred and (ii) identify the presence of false rings (FR). A false ring was defined as a growth ring in which the gradual transition from early- to latewood was interrupted by the occurrence of latewood-like cells in the earlywood or earlywood-like cells in the latewood.

Table 1. Average number of cells in growth rings 2003 and 2004 in the sampled trees from Jarafuel and Maigmó.

\begin{tabular}{ccc}
\hline & $\begin{array}{c}\text { Average number of cells } \\
\text { in previous ring }\end{array}$ & $\begin{array}{c}\text { Average number of cells } \\
\text { in current ring }\end{array}$ \\
\hline MAI & $17.90 \pm 7.14$ & $26.31 \pm 11.00$ \\
JAN & $40.70 \pm 21.00$ & $54.45 \pm 25.75$ \\
JAS & $36.86 \pm 15.80$ & $54.60 \pm 26.40$ \\
\hline
\end{tabular}

\section{Data analyses}

To enable comparison of different trees from different sites, with different growth potentials we standardized the observed number of cells in each sample using a modified procedure of Rossi et al. (2003):

$$
N c_{i j}=N_{i j} * \frac{A m}{A_{j}}
$$

Where:

$$
A m=\frac{\sum_{j=1}^{N} A_{j}}{N}
$$


$N c_{i j}=$ corrected number of $i$ cells in $j$ sample

$N_{i j}=$ counted number of $i$ cells in $j$ sample

$A m=$ average number of cells of the previous ring in a sampling site

$N=$ number of samples

$A_{j} \quad=$ average number of cells in previous ring of $j$-sample

In order to make comparisons between sites, we calculated percentages of PC, SW and MT with respect to the final number of cells in the growth ring 2004 (TR).

Differences in the mean number of cells in trees with and without tangential bands of resin canals (TRC) and in normal and false growth rings were tested using one-way ANOVA. In each case, variance homogeneity was tested using the Cochran test.

\section{RESULTS}

\section{Postcambial growth (PC cells)}

A wide cambium with a large number of cells (CC) and the presence of newly formed tracheids in postcambial growth (PC) indicated that the cambium was active (Fig. 2a). All investigated trees in the sampling sites, Maigmó (MAI), Jarafuel South (JAS), and Jarafuel North (JAN), already contained PC cells in the first sample, taken in mid-March (Fig. 3a). At this point, the cambium was on average eight cells wide in all three sites. The highest percentage of PC cells in relation to the final number of cells in the growth ring 2004 was recorded in mid-May (JAN-20\%, JAS-13\%, and MAI-21\%) (Fig. 3b). The percentage of trees containing PC cells decreased to a minimal value in August (JAS and JAN) or September (MAI) (Fig. 3a, b). At that time, the percentage of PC cells according to the final number of cells in the growth ring 2004 reached the lowest values, with only $1 \%$ on average, indicating a reduced rate of cell production (Fig. 3b). In addition, in 17, 33 and $50 \%$ of the trees at JAN, JAS, and MAI respectively, no PC cells were detected, indicating no cambial activity (Fig. 3a). Then, in August, the cambium contained on average eight (JAN), six (JAS) or five cells (MAI). The percentage of trees with PC cells later increased, reaching a new maximum in September (JAN$100 \%$ ) or October (JAS-100\% and MAI-83\%) (Fig. 3a). In addition, the percentage of PC cells in relation to the final number of cells in the completed growth rings of 2004 increased to 6\% (JAN), $3 \%$ (JAS), and 2\% (MAI), respectively (Fig. 3b). Subsequently, in December, only few trees had PC cells and a wide cambium (up to 7 cell layers), which was still active. Otherwise, cambial activity was finished by December in the majority of the trees with terminal latewood tracheids being in the final stages of development.

\section{Secondary wall formation (SW)}

Xylem cells undergoing secondary cell-wall formation and lignification (SW) (Fig. 2b-e) were already observed in all sampled trees from JAS in mid-March, suggesting that cambial activity started before our first sampling (Fig. 3c). In the other sites, SW cells were observed in mid-April in MAI and in mid-May in JAN (Fig. 3c). The percentages of SW cells in relation to the final number of cells in the growth ring 2004 in all investigated trees followed a bimodal pattern. The first peak was noted in May 


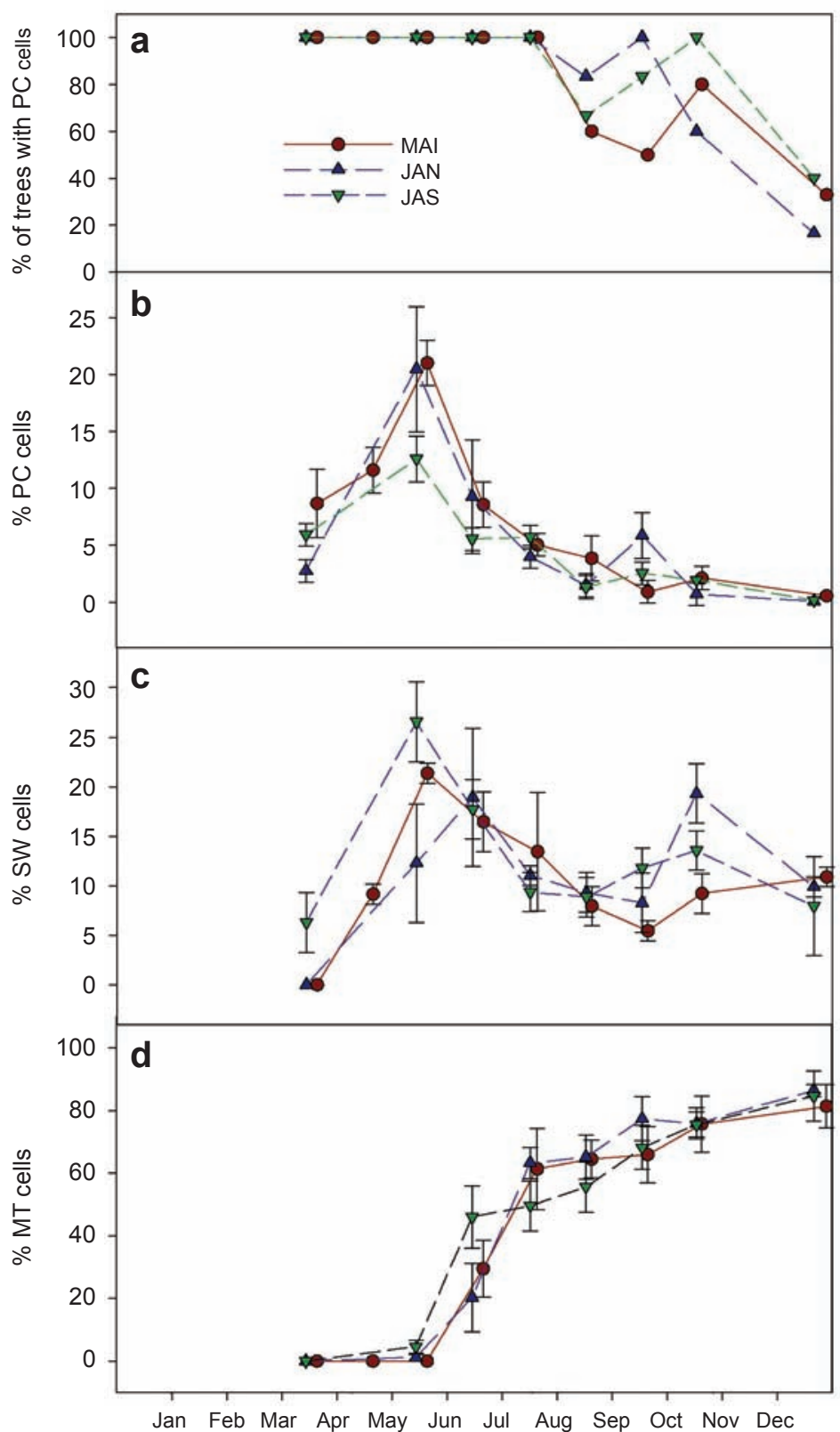

Figure 3. Tracheids in postcambial growth (PC). - a. Frequency of trees containing PC, with time, for the sampling sites Maigmó (MAI), red circle, Jarafuel North (JAN), blue triangle, and Jarafuel South (JAS), inverted green triangle. In all cases, error bars are depicted as standard errors. - b: Percentage of PC in respect to the final number of cells in the growth ring. $-\mathrm{c}$ : Percentage of tracheids undergoing secondary cell wall formation and lignification (SW) in relation to the final number of cells in the growth ring. - d: Percentage of mature tracheids (MT) in relation to the final number of cells in the growth ring with time. 
(MAI-22\% and JAS-27\%), or in June (JAN-19\%). It was followed by a decrease in the percentage of SW cells, with a minimum in August (JAS-9\%) or September (JAN$8 \%$ and MAI- $6 \%$ ). We detected a second peak of SW cells in October (JAS-14\% and JAN-20\%) or December (MAI-11\%). In December, the last formed tracheids adjacent to the cambium were still in final stages of cell-wall development in all investigated trees, so the inner parts of cell walls stained blue and protoplasmic content was still present in the lumina of the tracheids (Fig. $2 \mathrm{~g}$ ).

\section{Mature tracheids (MT)}

The percentage of mature tracheids (MT) (Fig. 2d) in relation to the final number of cells in the growth ring 2004 is shown in Figure 3d. The first completely differentiated tracheids were detected in mid-May (JAN and JAS) or in June (MAI). The addition of new, fully developed cells was the highest between May and June (JAS) and between June and August (MAI and JAN) as can be seen from the steep slope of the curves in Figure 3d. Afterwards, new mature cells are gradually added until the last sampling in December. The first mature latewood cells appeared in July (MAI) or August (JAN and JAS) (Fig. 4b).

\section{Total number of cells in the growth ring 2004}

In terms of the total number of cells $(\mathrm{PC}+\mathrm{SW}+\mathrm{MT})$ forming the growth ring 2004 (Fig. 4a) two main periods of cell production were detected, separated by a period of stagnation. The highest rate of tracheid production was observed in the period from March until June (JAS) or from March until July (JAN and MAI). During this time,

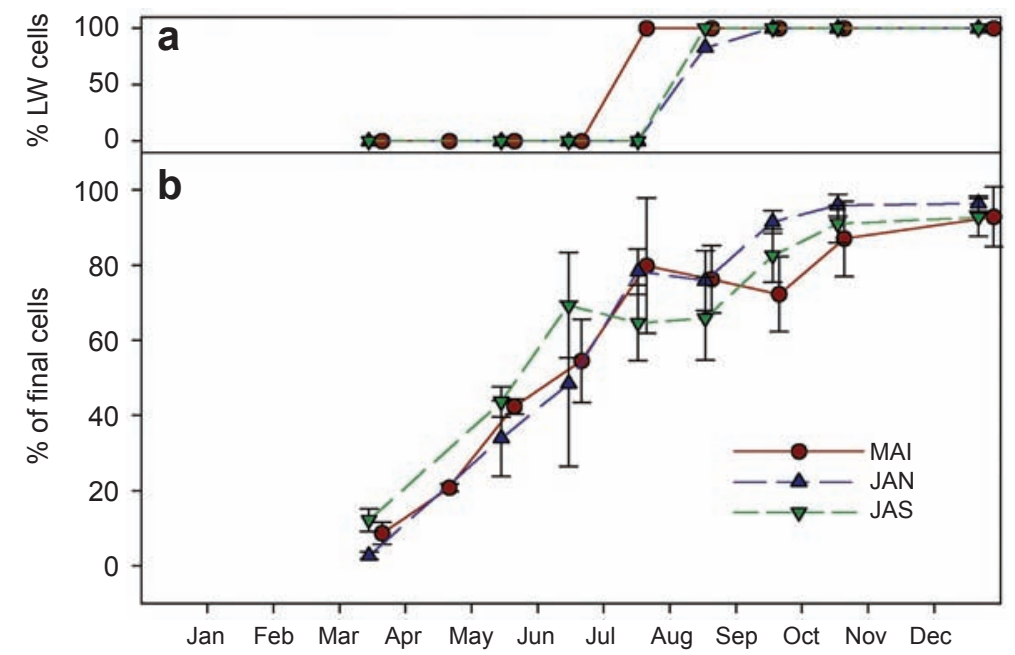

Figure 4. - a: Total percentage of new cells (PC, SW, MT) in relation to the final number of cells, with time for the sampling sites Maigmó (MAI), red circle, Jarafuel North (JAN), blue triangle, and Jarafuel South (JAS), inverted green triangle. - b: Percentage of latewood cells $(\mathrm{LW})$ in relation to the total number of new cells at each sampling period. In all cases, error bars are depicted as standard errors. 
the major part, i.e. $70 \%$ (JAS) or $80 \%$ (JAN and MAI), of the growth ring 2004 was formed. After a stagnation of one to two months, between July and September, the second period of cell production started in September (JAN and JAS) or October (MAI) and continued until December (Fig. 4a). During this second growth peak respectively $20 \%$ (JAN and MAI) and $30 \%$ (JAS) of the growth ring was produced.

\section{Formation of resin canals $(R C)$ and false rings $(F R)$}

The first solitary resin canals (RC) were formed in May (JAS) or June (MAI and JAN) in all investigated trees. The first tangential bands of resin canals (TRC) (Fig. $2 \mathrm{f}$ ), were recorded in June (JAS and JAN) and in July (MAI), respectively. They were

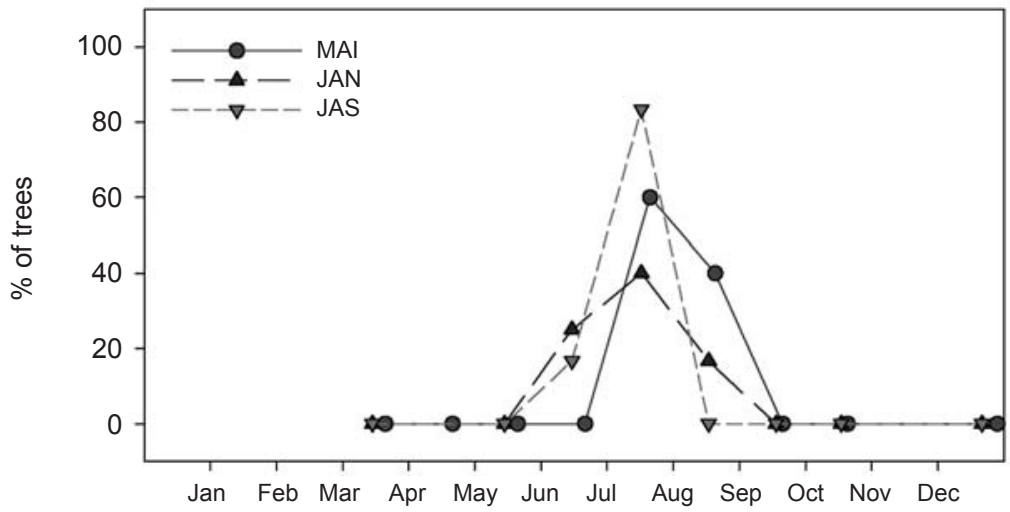

Figure 5. Percentage of trees containing tangential bands of resin canals (TRC) surrounded by tracheids in postcambial growth (PC) at sampling sites Maigmó (MAI), Jarafuel North (JAN) and Jarafuel South (JAS).

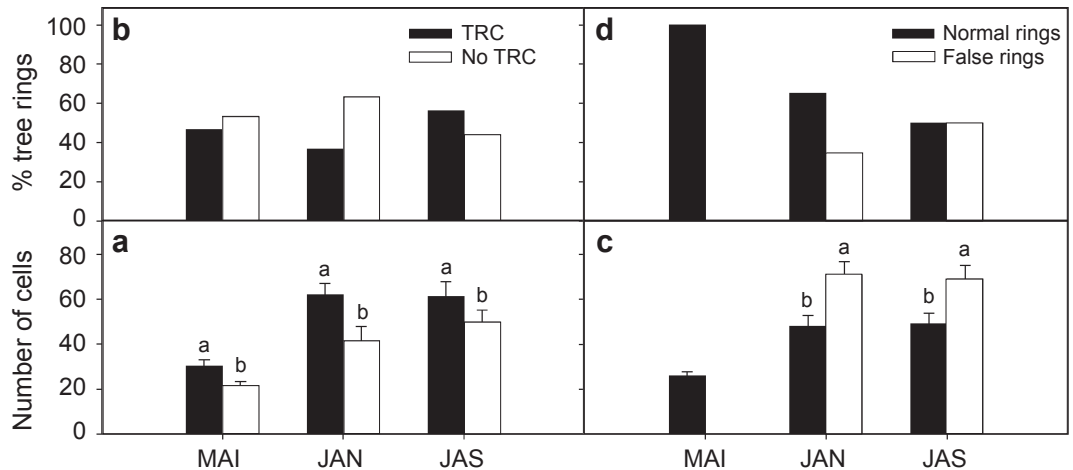

Figure 6. Percentage of trees containing tangential bands of resin canals (TRC). - a: Mean number of cells ( \pm standard errors) in trees with and without TRC. Different letters indicate significant differences $(\mathrm{p}<0.05)$. - b: Frequency of trees with and without TRC in the growth rings formed in 2004 at each sampling site, Maigmó (MAI), Jarafuel North (JAN) and Jarafuel South (JAS). Percentage of trees containing false rings. $-\mathrm{c}$ : Mean number of cells ( \pm standard errors) in normal and false growth rings. Different letters indicate significant differences $(\mathrm{p}<0.05) .-\mathrm{d}$ : Frequency of trees with normal and false growth rings in 2004 at each sampling site. 
surrounded by tracheids in the phase of postcambial growth (PC) indicating that the RC were formed recently. In July, 60\% (MAI), $40 \%$ (JAN) and $83 \%$ (JAS) of all trees contained TRC surrounded by PC cells (Fig. 5). Samples taken in April 2005 showed that altogether $47 \%$ (MAI), $37 \%$ (JAN), and $56 \%$ (JAS) of the investigated trees contained TRC (Fig. 6b). They were either located in the transition zone between earlywood and latewood or in the latewood. TRC were observed in wider growth rings with more than 20 cells in MAI and more than 60 cells in JAN and JAS (ANOVA, p<0.05; Fig. 6a).

The anatomical structure of a false ring (FR) is shown in Figure $2 \mathrm{~g}$. Inspection of the completed growth rings 2004 revealed that FR only occurred in trees from Jarafuel, with $35 \%$ of the trees at JAN and $50 \%$ of the trees at JAS showing FR, whereas in trees from MAI no FR were detected (Fig. 6d). In trees from JAN and JAS, FR were observed only in growth rings wider than 70 cells (ANOVA, p <0.05, Fig. 6c). In trees from MAI, the growth rings formed in 2004 were considerably narrower, with a mean value of 26 cells in a radial row.

\section{DISCUSSION}

Pinus halepensis has been characterized as a sensitive Mediterranean species based on the strong response of radial growth dynamics to changes in climatic conditions (Lev-Yadun 2000). It has also been suggested that the cambium is able to remain active throughout the whole year when climate conditions are favourable (Liphschitz et al. 1984). At other times, cambial activity can stop for one to three months during winter depending on the prevalence of low temperatures (Gindel 1967) which can considerably influence tree vigour (Oppenheimer 1945). In addition, cambial activity of Aleppo pine can slow down or even stop during summer drought (Gindel 1967; Liphschitz et al. 1984) and later again resume when more favourable, i.e. wet conditions appear in autumn (Liphschitz et al. 1984).

Our study showed that during 2004 the dynamics of cambial activity in Pinus halepensis from three different stands in Spain was characterized by two major growth phases, one in spring and another in autumn, interrupted by a period with low or no cambial activity during summer. This is in agreement with results of other studies on Aleppo pine (Gindel 1967; Attolini et al. 1990; Nicault et al. 2001). Cell division in the cambium already started before our first sampling in mid-March and ended in the majority of trees between November and December, indicating that cambial activity lasted at least eight months. Xylem cells of trees from JAS were already undergoing cell-wall thickening and lignification in mid-March, suggesting that divisions at the cambium started at least three to four weeks before the first sampling. Earlier onset of cambial activity in trees from JAS compared to other plots is most likely due to higher temperatures in February on the south slope (JAS) in Jarafuel. It is well known that temperature is a very important factor promoting cambial activity at the very beginning of the growing period (Oribe et al. 2003; Rossi et al. 2006; Gričar et al. 2007). Our results were similar to those of Nicault et al. (2001), who also reported a growing period of eight months for Pinus halepensis from South France starting between February and March and lasting until October. Gindel (1967) reported that cambial 
activity in Aleppo pine from Mount Carmel, Israel, finished at the end of November. However, we found, that the process of differentiation of the terminal latewood tracheids was still ongoing in December. This fits the observation of Schweingruber (1996) and Gričar et al. (2005) who found that secondary cell-wall formation and lignification in the last-formed latewood tracheids continues after the cessation of cambial activity as their development can take up to eight weeks.

Our results show a reduced production of new tracheids in August. However, a complete interruption in cambial activity was only observed in a few sampled trees. We found that during summer most sampled trees were still growing, but at a very low rate. Hence, we prefer to speak of a "low-activity period" instead of a true "summer dormancy". It is reported for Pinus halepensis that this decrease in cambial activity (= reduction in cell division rate) on average lasts for two months in summer, either in JuneJuly (Liphschitz et al. 1984), July-August (Nicault et al. 2001) or August-September (Gindel 1967). Attolini et al. (1990) and Nicault et al. (2001) used dendrometers to follow cambial activity and, although they did not detect any radial increase of the stems during summer, they suggested that the cambium probably was not dormant because the trees resumed activity in autumn. Dendrometers have often been successfully used to study annual radial growth dynamics. However, this method shows limitations in recording cambial activity with a high temporal resolution as the measurements monitor both diurnal variation in stem circumference due to shrinkage and swelling of the phloem and xylem as well as cambial activity, i.e. cell division (e.g. Zweifel et al. 2006). This means that a summer slow down or dormancy in cambial activity is difficult to detect.

The histological methods used in our study made it possible to reconstruct cambial activity with a high temporal resolution and moreover study the initiation and formation of specific wood-anatomical characteristics such as resin canals and false rings throughout the growing season.

The occurrence of solitary resin canals is a characteristic feature in wood of Pinus halepensis. It appears that, independently of site conditions, the production of resin canals is positively related to summer temperature (Rigling et al. 2001). However, it is still an open question whether or not the formation of this secretory tissue could be related to drought stress (Rigling et al. 2003). In 2004, the decrease in precipitation and rise in temperatures at our study locations started in June (Fig. 1c, d). At all sites the first solitary resin canals (RC) were formed in May (JAS) or June (MAI and JAN). Furthermore, by then, the first tangential bands of resin canals (TRC) were recorded in more than $25 \%$ of the trees from Jarafuel (JAS and JAN) and in around $20 \%$ of the trees from Maigmó, though the majority of the investigated trees formed TRC in July when drought stress increased. Generally, TRC were observed in wider growth rings, with more than 20 cells in a radial row in MAI and more than 60 cells in a radial row in JAN and JAS. The TRC were located either in the transition zone from earlywood to latewood (JAN and JAS) or in latewood (MAI). Differences in the relative position of TRC in the growth rings of 2004 were detected among sites because of different timing of latewood formation. In July, when the majority of TRC were formed, all trees from Maigmó were already in the phase of latewood formation, whereas in trees from 
Jarafuel (with wider growth rings) the production of latewood cells started about one month later. Rigling et al. (2003) found the same for Pinus sylvestris and they suggest that resin canals are formed as a response to increasing drought stress in the second half of the growing season.

According to Bräuning (1999), false rings (FR) contain information about climate events that occur in the growing season during periods when the overall growing conditions are not extremely harsh for trees. It has been described that factors triggering the formation of FR have to last long enough to ensure that auxins will reactivate the cambium (Panshin \& DeZeeuw 1980). Moreover, cells in the differentiating phase must be present when abnormal climate conditions occur (Schweingruber 1996) and a sufficient number of cell rows must be produced to ensure the required temporal resolution (Bräuning 1999). In all three sampling sites, we recorded cambial activity during summer and reactivation in autumn, but FR appeared only in JAS and JAN. The reason for the absence of FR in trees from MAI could be the generally lower growth rate of the trees at this site (Table 1) with the consequence of a less distinctive resumption of cell division in autumn. It was detected in a small number of trees and only a few cells with narrow radial dimensions and thick cell walls were produced during this period. Rainfall at the end of the summer drought appears to be decisive for cambial reactivation in autumn (Nicault et al. 2001). In view of the small amount of rain received at MAI in autumn $(18 \mathrm{~mm})$, it seems that there was not enough precipitation to produce a sufficient number of cell rows and/or affect cell size and cell-wall thickness to form FR. Conversely, JAN and JAS received an above-average amount of rain (mainly in September), with the consequence that the trees formed FR. In addition, the average number of cells in the growth rings of 2004 in trees from Jarafuel was nearly double the average of those from Maigmó.

The frequency of false rings (FR) was higher in JAS than in JAN, which is in agreement with Rigling et al. (2002) who found that the frequency of FR in Pinus sylvestris was higher at the southern slope compared to the northern slope. From a structural point of view, on the northern slope cell dimensions often decreased progressively during summer and autumn, while cells produced during summer on south-facing slopes were considerably narrower than those produced during the resumption of cambial activity. In accordance with this, it can be concluded that summer drought plays an important role in false-ring formation, as it is responsible for the formation of small cells (Kozlowski 1971; Fritts 1976). Since precipitation in autumn was high and similar on both slopes, it seems that the intensity of drought stress was decisive for the production of FR.

In conclusion, we found pronounced characteristics in cambial activity throughout the year 2004 which can be ascribed to the course of the climate conditions in this specific year: a relatively early reactivation of the cambium (before March), two major growth phases (one in spring and another in autumn), and a prolonged cambial activity (till December in some trees). These characteristics are a response to above-average precipitation during spring, below-average precipitation in summer, and relatively dry conditions in autumn, especially at Maigmó.

However, as in the Mediterranean the climate strongly differs from year to year it is necessary to continue studies on cambial activity throughout several years in order to 
assess the influence of climate on wood formation and to better understand the physiological processes behind these climate-growth relationships.

\section{ACKNOWLEDGEMENTS}

This study is supported by the Spanish Ministry of Education and Science (contracts: CGL200504270 and REN2003-07453) and by the Ministry of Higher Education, Science and Technology of the Republic of Slovenia, Research Program "Lesarstvo". We thank Consejeria Valenciana de Medio Ambiente (Regional Ministry of Environment) for their assistance and especially Ramón Sánchez, Vicente Colomer and Pedro Esteban Sánchez for their collaboration in site selection and sampling procedures. The field and laboratory work was to a great part made by Isabel Dorado. We thank Peter Cunder, José Huesca and Martin Zupančič for their help in the laboratory and Instituto Nacional de Meteorología for providing climatic data for our study. We owe particular thanks to the editor and two anonymous reviewers for their critical and valuable comments on the manuscript.

\section{REFERENCES}

Attolini, M.R., F. Calvani, M. Galli, T. Nanni, L. Ruggiero, E. Schaer \& F. Zuanni. 1990. The relationship between climatic variables and wood structure in Pinus halepensis Mill. Theoretical and Applied Climatology 41: 121-127.

Barbéro, M., R. Loisel, P. Quézel, D.M. Richardson \& F. Romane. 1998. Pines of the Mediterranean Basin. In: D.M. Richardson (ed.), Ecology and biogeography of Pinus: 153-170. Cambridge University Press, Cambridge, UK.

Bräuning, A. 1999. Dendroclimatological potential of drought-sensitive tree stands in southern Tibet for the reconstruction of monsoonal activity. IAWA J. 20: 325-338.

Cherubini, P., B.L. Gartner, R. Tognetti, O.U. Bräker, W. Schoch \& J.L. Innes. 2003. Identification, measurement and interpretation of tree rings in woody species from Mediterranean climates. Biol. Rev. 78: 119-148.

Fahn, A. \& E. Zamski. 1970. The influence of pressure, wind, wounding and growth substances on the rate of resin duct formation in Pinus halepensis wood. Israel J. Bot. 19: 429-446.

Fritts, H.C. 1976. Tree rings and climate. Academic Press, London.

Gartner, B.L. 1995. Patterns of xylem variations within a tree and their hydraulic and mechanical consequences. In: B.L. Gartner (ed.), Plant stem: Physiology and functional morphology: 125-149. Academic Press Inc., San Diego, California, USA.

Gindel, I. 1967. Cambial activity as a function of the intensity of transpiration in Pinus halepensis Mill. Proc. XVI IUFRO Congr. München 1967, vol. IV, sect. 23: 188-206.

Gričar, J., K. Čufar, P. Oven \& U. Schmitt. 2005. Differentiation of terminal latewood tracheids in silver fir during autumn. Ann. Bot. 95: 959-965.

Gričar, J., M. Zupančič, K. Čufar \& P. Oven. 2007. Regular cambial activity and xylem and phloem formation in locally heated and cooled stem portions of Norway spruce. Wood Sci. and Technol. 41 (6): 463-475.

Kozlowski, T.T. 1971. Growth and development of trees. Vol. II. Cambial growth, root growth and reproductive growth. Academic Press, New York.

Kramer, P.J. \& T.T. Kozlowski. 1979. Physiology of woody plants. Academic Press, New York.

Lev-Yadun, S. 2000. Wood structure and the ecology of annual growth ring formation in Pinus halepensis and P. brutia. Ecology, biogeography and management of Pinus halepensis and P. brutia. In: G. Ne'eman \& L. Trabaud (eds.), Forest ecosystems in the Mediterranean Basin: 67-78. 
Liphschitz, N. \& S. Lev-Yadun. 1986. Cambial activity in evergreen and seasonal dimorphics around the Mediterranean. IAWA Bull. n.s. 7: 145-153.

Liphschitz, N., S. Lev-Yadun, E. Rosen \& Y. Waisel. 1984. The annual rhythm of activity of the lateral meristems (cambium and phellogen) in Pinus halepensis Mill. and Pinus pinea L. IAWA Bull n.s. 5: 263-274.

Messeri, A. 1948. L'Evoluzione della cerchia legnosa in Pinus halepensis Mill. In Bari del luglio 1946 al luglio 1947. Nuov. Giorn. Bot. Ital. n.s. 55: 111-132.

Mitrakos, K. 1980. A theory for Mediterranean plant life. Acta Oecol. 1: 245-252.

Nicault, A., C. Rathgeber, L. Tessier \& A. Thomas. 2001. Observations sur la mise en place du cerne chez le pin d'Alep (Pinus halepensis Mill.): confrontation entre les mesures de croissance radiale, de densité et les facteurs climatiques. Ann. For. Sci. 58: 769-784.

Oppenheimer, H.R. 1945. Cambial wood production in stems of Pinus halepensis. Palest. J. Bot. Rehovot Series 5: 22-51.

Oribe, Y., R. Funada \& T. Kubo. 2003. Relationship between cambial activity, cell differentiation and the localization of starch in storage tissues around the cambium in locally heated stems of Abies sachalinensis (Schmidt) Masters. Trees 17: 185-192.

Panshin, A. \& C. DeZeeuw. 1980. Textbook of wood technology. McGraw-Hill Series in Forest Resources. McGraw-Hill Book Company, New York.

Priya, P.B. \& K.M. Bhat. 1998. False ring formation in teak (Tectona grandis L.f.) and the influence of environmental factors. For. Ecol. \& Management 108: 215-222.

Raventós, J., M. De Luís, I. Dorado \& M. J. Gras. 2004. Dendroecology on East Spain Mediterranean inland/coast gradient: Tree ring anomalies on Pinus halepensis. Proc. 10th MEDECOS Conf.; Arianoutsou \& Papanastasis (eds.). Millpress Science Pub., Rotterdam. 6 pp.

Raventós, J., M. De Luís, M. J. Gras, K. Čufar, J.C. González-Hidalgo, A. Bonet \& J.R. Sánchez. 2001. Growth of Pinus pinea and Pinus halepensis as affected by dryness, marine spray and land use changes in a Mediterranean semiarid ecosystem. Dendrochronologia 19: 211-220.

Reid, R.W. \& J.A. Watson. 1966. Size, distribution and number of vertical resin ducts in Lodgepole pine. Can. J. For. Res. 44: 519-525.

Rigling, A., O. Bräker, G. Schneiter \& F.H. Schweingruber. 2002. Intra-annual tree-ring parameters indicating differences in drought stress of Pinus sylvestris forests within the Erico-Pinion in the Valais (Switzerland). For. Ecol. \& Management 163: 105-121.

Rigling, A., H. Brühlhart, O.U. Bräker, T. Forster \& F.H. Schweingruber. 2003. Effects of irrigation on diameter growth and vertical resin ducts production in Pinus sylvestris L. on dry sites in the central Alps, Switzerland. For. Ecol. \& Management 175: 285-296.

Rigling, A., P.O. Waldner, T. Forster, O.U. Bräker \& A. Pouttu. 2001. Ecological interpretation of tree-ring width and intraannual density fluctuations in Pinus sylvestris on dry sites in the central Alps and Siberia. Can. J. For. Res. 31: 18-31.

Rossi, S., A. Deslauriers, T. Anfodillo, H. Morin, A. Saracino, R. Motta \& M. Borghetti. 2006. Conifers in cold environments synchronize maximum growth rate of tree-ring formation with day length. New Phytol. 170: 301-310.

Rossi, S., A. Deslauriers \& H. Morin. 2003. Application of the Gompertz equation for the study of the xylem cell development. Dendrochronologia 21: 33-39.

Schweingruber, F.H. 1978. Microscopic wood anatomy. Swiss Fed. Inst. For. Res., Birmensdorf.

Schweingruber, F.H. 1996. Tree rings and environment. In: Dendroecology. Swiss Federal Research Institute WSL, Birmensdorf and Verlag Haupt, Bern.

Serre, F. 1976. Relations between tree growth and climate in Aleppo pine. I \& II. Oecol. Plant. 11: 143-171; 201-224. 
Susmel, L., F. Viola \& G. Bassato. 1976. Ecologia della lecceta del Supramonte di Orgosolo (Sardegna Centro-orientale). Cedam, Padova, Italy.

Terradas, J. \& R. Savé. 1992. The influence of summer and winter stress and water relationships on the distribution of Quercus ilex L. Vegetatio 99/100: 134-135.

Wimmer, R. \& M. Grabner. 1997. Effects of climate on vertical resin duct density and radial growth of Norway spruce (Picea abies (L.) Karst.). Trees 11: 271-276.

Wimmer, R., G. Strumia \& F. Holawe. 2000. Use of false rings in Austrian pine to reconstruct early growing season precipitation. Can. J. For. Res. 30: 1691-1697.

Zweifel, R., F. Zeugin, L. Zimmermann \& D.M. Newbery. 2006. Intra-annual radial growth and water relations of trees - implications towards a growth mechanism. J. Experim. Bot. 57: $1445-1459$. 